\title{
Developing a Happiness-Based Native Positive Parenting Model Using Grounded Theory and Developing an Educational Package Based on the Model
}

\author{
Azam Bahrami* \\ Department of Psychology, University of Esfahan, Iran
}

Submission: April 23, 2017; Published: May 23, 2017

*Corresponding author: Azam bahrami, Department of Psychology, University of Esfahan, Iran, Email: azam_bahrami_51@yahoo.com

Abstract

This study aimed to develop a happiness-based native positive parenting model and creating a related educational package. It was a qualitative study based on the Grounded Theory conducted in 2014 in the city of Qom, Iran. The study population included family experts and a group of mothers with high happiness scores. Participants were selected using the purposeful sampling method. Data was collected through semi-structured in-depth interviews and the triangulation method. Data analysis was performed using the grounded theory approach by the inductive reasoning. The conceptual codes were extracted excluding the shared ones. Research findings included information on factors related to happiness-based positive parenting then classified into 7 primary and 26 sub-components as follows:

The primary components included emotional intelligence, marital relationship quality, value system, parenting style, life skills, positive health capitals, and flourishing. Each of the 26 sub-components composed of other aspects resulted in a total of 268 components. Finally, a native model consisting of 7 dimensions was designed based on the concepts extracted from the interviews with the family experts, happy mothers, and investigations. The results revealed that one of the most important factors influencing family happiness is the quality of marital relationship. In fact, parenting is reinforced by strengthening the marital relationship and improving this relationship quality increases the family happiness.

Keywords: Family; Happiness; Grounded Theory; Emotional Intelligence; Marital Relationship Quality; Value System; Parenting Style; Life Skills; Positive Health Capitals; Flourishing

\section{Introduction}

Positive psychology is currently considered as a new psychological movement. Scientific and investigational interests of positive psychological perspective are focused on thorough understanding of the wide spectrum of human experiences in terms of diseases, pain, discomfort, and lack of health and wellbeing. Seligman et al. [1,2] argued that positive psychology related to humans happiness, bliss, and a happy life was the satisfactory one. Positive psychology considers this lifestyle a perfect one [1,2]. In fact, happiness is defined as a sense of satisfaction and content (Hills, Argyl, and Riuos). Positive psychology studied thoroughly by Martin Seligman, strongly emphasized capabilities, positive social and personal life aspects, thanksgiving, and appreciation [3]. According to Diener and Seligman, in positive psychology, the "good life" referred to a state of relative happiness dominance (i.e. mental or material well-being and positive or pleasant emotions) over consciously unpleasant and negative emotional experiences (such as anxiety, depression, and anger). Hence, happiness is one of the most fundamental concepts of positive psychology. Recent investigations have shown that people can learn to be happy, and human happiness can be improved sustainably (Lyubomirsky).

A healthy society depends on well-being of its families; mental health and favorable interactions between the members represent healthy families (Sadok \& Sadok). Family is one of the most important institutions of a society, which contributes to the children's personality development and plays a pivotal role in protecting their mental health. Family is the first context in which children think, feel, behave, learn, and grow (Szapocznik, Hervis, \& Schwartz). 
Happiness has a major importance for human mental health and felicity, and people all around the globe are actively and increasingly seeking for improved subjective well-being (or what is known as happiness) (Lyubomirsky). Evidence suggests that the signs of subjective well-being including life satisfaction and positive feelings are related to positive communicative outputs, work, and physical wellness (Lyubomirsky, King, Diener). Family relations are in part based on marital relationship described as the most important and substantial human relationship; it plays a fundamental role in developing family relations and shaping the future generation (Taniguchi, Freeman, Taylor, \& Malcarne). Investigations have always confirmed the effects of the quality of marital relationships on physical and mental health, as well as socio-psychological adjustment of family members and children regarding different personal and social aspects of their lives (Annbuysse \& Vanoost, Yu-Jin \& Young-Ju). Some studies have revealed that decreased marital quality is associated with a decrease in happiness, life satisfaction, self-esteem, and physical and mental health. Therefore, given the crucial role of marital satisfaction in mental health and children's happiness, it should be given more emphasis (Byrn \& Carr).

Investigations indicated that some factors such as intimate relationship with parents, attachment, parental monitoring, and parents' marital relationship are related to children's and adolescents' behavior shaping and their upbringing (Ralph, Thompson, Sofronoff \& Gardiner). Improving the children's mental health of children should be addressed by improving the quality of child rearing and the mother-child relationship (Sanders). There are a set of capabilities, skills and components can increase happiness by affecting mental health in humans. Emotional intelligence is one of the influencing variables in this regard; it consists of skills, talents, and non-cognitive abilities that increase the person's success in coping with environmental demands and pressures. Therefore, emotional intelligence is one of the important factors directly affects the person's mental health and success in life (Bar-On). Values are also considered as substantial aspects of social life and personality defined as meta-situational goals determining the strategic principles of a person's life (Shechtman).Values invoke a motivational force and are energy sources influencing remarkably the overall quality, personal lifestyle, and human [4]. Values also influence marital life satisfaction and are among the important factors affecting considerably the future of marital life and child rearing. The primary features include positive emotions, participation, interest, significance, and goal, while secondary characteristics consists of self-esteem, optimism, improvability, vitality, selfdetermination, and positive flourishing relations [1,2].

Recent studies on positive psychology showed that happiness is learned and human happiness can be improved sustainably (Lyubomirsky). The parents play an important role in high quality child rearing, and happiness can also have noticeable effect on different aspects of life including the children development; therefore, establishing a model in order to achieve these objectives is a significant step to be taken. Several investigations regarding the effective factors on family happiness have already been conducted by researchers in different countries, as well as by Iranian ones; however, no local program has been yet established. In any case, there has been a debate whether the increasing happiness activities have equal effectiveness for individuals with different cultural backgrounds; developing a native model in this study may address this issue. Due to the recent considerable necessity of positive psychological interventions such as happiness interventions, the present research was carried out with an aim to determine the effective factors on the family happiness. As a result, the following question raised considering the objective of this research: How does the happiness-based native positive parenting model function? And, what are the effective factors on the family happiness?

\section{Research Method}

\section{Research Method, Statistical Population, and Sample:}

This qualitative study conducted using the grounded theory. A qualitative study consists of interpretive techniques used to describe, decode, translate, and understand socialenvironmental meanings and phenomena [5]. During the past two decades, many different grounded theory styles have been introduced, so they have been called the grounded theory family (Bryant \& Charmas). The present study was designed to identify the factors associated with happy family by interviewing family experts and some happy parents, and reviewing the research background, documents, and evidence. Data analysis, coding, and categorization were carried out during the data collection phase based on the grounded theory; information was collected and analyzed until theoretical saturation was achieved regarding the research objective. In other words, in the grounded theory, collected data is encoded in three steps. Notions, categories, and theories are derived from codes, notions, and categories, respectively.

The statistical population for this research consisted of family experts and happy parents. Experts were interviewed using the non-probability sampling method. To this end, eight family and adolescence skilled and experienced experts were interviewed. Experts were selected based on the following criteria: 1) their interest for being interviewed; 2) holding an M.S. or a higher degree in consulting, psychology, and family; 3) having at least ten years of experience providing family consulting services. Happy mother's for interviews were selected using the purposeful sampling method based on the following criteria: 1) obtaining the minimum happiness score from the Oxford Happiness Questionnaire; 2) being interested in participating in the interviews. The sampling techniques (interviewing with experts and scholars; reviewing documents, publications, and books) are more flexible in qualitative studies 


\section{Psychology and Behavioral Science International Journal}

compared with quantitative investigations, and this flexibility is due to the unpredictable nature of qualitative research projects; therefore, sampling cannot be specifically planed prior to the research, as particular decisions are made during the course of the study, and the information is collected to the point of saturation [6]. Subsequently, analyses, notion statement, initial coding, categorization, extraction of basic psychological notions out of the data, and notion development were carried out.

In this research, in-depth interviews were the means of data collection, which were carried out in accordance with the interview guidelines. The scope of questions raised by the researcher included the following areas: 1) factors contributing to family happiness; 2) factors improving family happiness; 3 ) strategies for making a happy family.

In the grounded theory, categories were identified and encoded after completing the interviews and preparing analytical notes. They were then interpreted and the psychological variables were derived. First, initial (open) coding was carried out using the raw data and remarks of the interviewees, and then using the most significant and frequent initial codes, a large portion of data was filtered and similar codes were put into one category. Hence, each category (or axial code) was assigned several similar, overlapping, and synonymous codes. Data was encoded using NVio10. To assess and examine the validity of the contents of the interviews and the analysis, and the accuracy and integrity of the coding process, four professors of family consulting and psychologists were asked to revise and modify the coding process. The integration method was also used to increase the validity and reliability. To this end, relevant studies consisting of literature including dissertations in Farsi, as well as Persian and English books, journals and articles were reviewed and related categories were identified. The codes and categories derived from the dissertations were compared with codes and categories obtained from investigations. In addition, theoretical saturation of the data and finally the categories were confirmed. The outcome of all these steps was the happiness-based native positive parenting model. Table 1 presents the demographic characteristics of the research participants (Table 1).

Table 1: Characteristics of the participants (family experts and happy mother's).

\begin{tabular}{|c|c|c|c|c|}
\hline $\begin{array}{c}\text { Participant } \\
\text { population }\end{array}$ & Age & Education & Gender & Frequency \\
\hline $\begin{array}{c}\text { Consultant and } \\
\text { psychologist }\end{array}$ & $46-48$ & Ph.D. & Male & $13 \%$ \\
\hline $\begin{array}{c}\text { Consultant and } \\
\text { psychologist }\end{array}$ & $50-52$ & M.S & Male & $9 \%$ \\
\hline $\begin{array}{c}\text { Consultant and } \\
\text { psychologist }\end{array}$ & $42-46$ & Ph.D. & Female & $9 \%$ \\
\hline Psychologist & 40 & M.S. & Female & $4 \%$ \\
\hline
\end{tabular}

\begin{tabular}{|c|c|c|c|c|}
\hline Happy mother & $33-46$ & $\begin{array}{c}\text { High } \\
\text { school } \\
\text { education }\end{array}$ & Female & $22 \%$ \\
\hline Happy mother & $32-50$ & $\begin{array}{c}\text { High } \\
\text { school } \\
\text { graduate }\end{array}$ & Female & $26 \%$ \\
\hline Happy mother & $46-49$ & $\begin{array}{c}\text { Associate } \\
\text { degree }\end{array}$ & Female & $9 \%$ \\
\hline Happy mother & $43-48$ & B.S. & Female & $9 \%$ \\
\hline
\end{tabular}

\section{Results}

The three-stage coding of the collected data resulted in the extraction of the notions and categories. According to the psychological process described, using the open, axial, and selective coding phases, the codes related to the research objective were selected from a large number of initial data. Afterwards, a notion was derived from several codes. Similarly, other codes were converted into notions, and then the final notion was developed. Subsequently, several notions were categorized into one category and the research categories were established. Of these categories, one category was considered as the central category to form the grounded theory components of this research along with the other categories. The central category for this research was marital satisfaction, and other categories meaningful in relation to it. Tables $2 \& 3$ present the notions constituting the categories. Due to the limited scope of this paper, the findings from the interviews with the experts and happy mothers have been demonstrated (Table 2).

Table 2: Contents of interviews with family experts.

\begin{tabular}{|c|c|c|}
\hline $\begin{array}{l}\text { Statements and } \\
\text { expressions }\end{array}$ & Open coding & Axial coding \\
\hline $\begin{array}{l}\text { The couple } \\
\text { should convey their } \\
\text { positive emotions. }\end{array}$ & $\begin{array}{l}\text { Emotional } \\
\text { conveyance }\end{array}$ & $\begin{array}{l}\text { marital } \\
\text { relationship quality }\end{array}$ \\
\hline $\begin{array}{c}\text { Willingness } \\
\text { to cooperate with } \\
\text { others brings about } \\
\text { happiness. }\end{array}$ & Cooperation & Social values \\
\hline $\begin{array}{c}\text { Political, } \\
\text { economic, and social } \\
\text { stability of the } \\
\text { society influence } \\
\text { families and their } \\
\text { happiness. }\end{array}$ & $\begin{array}{l}\text { Increased social } \\
\text { security }\end{array}$ & Political values \\
\hline $\begin{array}{l}\text { Music leads } \\
\text { to catharsis and } \\
\text { happiness. }\end{array}$ & $\begin{array}{c}\text { Paying attention } \\
\text { to art and artistic } \\
\text { works }\end{array}$ & Artistic values \\
\hline $\begin{array}{c}\text { Practicing } \\
\text { religion leads to } \\
\text { happiness and joy. }\end{array}$ & $\begin{array}{r}\text { Addressing } \\
\text { religious affairs }\end{array}$ & Spiritual values \\
\hline $\begin{array}{c}\text { Coping with } \\
\text { challenges properly }\end{array}$ & $\begin{array}{c}\text { Problem } \\
\text { solving and anger } \\
\text { management }\end{array}$ & Life skills \\
\hline
\end{tabular}




\section{Psychology and Behavioral Science International Journal}

\begin{tabular}{|c|c|c|}
\hline $\begin{array}{c}\text { When we feel } \\
\text { good, others feel } \\
\text { good. }\end{array}$ & Sympathy & Positive health \\
\hline $\begin{array}{c}\text { Active role of } \\
\text { fathers in child } \\
\text { rearing increases } \\
\text { happiness. }\end{array}$ & $\begin{array}{c}\text { Parent-child } \\
\text { relationship quality }\end{array}$ & Parenting style \\
\hline $\begin{array}{c}\text { Taking } \\
\text { responsibility in life } \\
\text { leads to happiness. }\end{array}$ & $\begin{array}{c}\text { Commitment and } \\
\text { accountability }\end{array}$ & $\begin{array}{c}\text { Emotional } \\
\text { intelligence }\end{array}$ \\
\hline
\end{tabular}

In this table, the results of the interviews with the family experts, analysis, and initial notions have been presented. The points discussed in the interviews were classified into several major topics. Variables mentioned by the experts were summarized into 44 raw statements and were classified as 90 open coding and 10 axial coding. The participant no.6: "Families should set aside some money for happiness. They should not just allocate their financial resources for some issues such as traveling, but addressing other aspects of their lives." Open coding: prioritizing happiness and allocating a budget for it; axial coding: entertainment and recreation (Table 3).

Table 3: Factors influencing the family happiness from the mothers' viewpoint.

\begin{tabular}{|c|c|c|}
\hline $\begin{array}{l}\text { Statements and } \\
\text { expressions }\end{array}$ & Open coding & Axial coding \\
\hline $\begin{array}{l}\text { We appreciate each } \\
\text { other's presence. }\end{array}$ & Marital interaction & $\begin{array}{l}\text { marital relationship } \\
\text { quality }\end{array}$ \\
\hline $\begin{array}{l}\text { We never lie to each } \\
\text { other. }\end{array}$ & $\begin{array}{l}\text { Honesty in words } \\
\text { and action }\end{array}$ & $\begin{array}{l}\text { Proper family } \\
\text { interactions }\end{array}$ \\
\hline $\begin{array}{l}\text { Flexibility to accept } \\
\text { each other's faults. }\end{array}$ & $\begin{array}{l}\text { Being open to } \\
\text { criticism }\end{array}$ & $\begin{array}{l}\text { Positive health } \\
\text { capital }\end{array}$ \\
\hline $\begin{array}{l}\text { We express our } \\
\text { desires logically } \\
\text { and do not behave } \\
\text { selfishly. }\end{array}$ & Problem solving & Life skills \\
\hline $\begin{array}{l}\text { We trust in God in all } \\
\text { things. }\end{array}$ & Trusting in God & Spiritual values \\
\hline $\begin{array}{l}\text { Attending social } \\
\text { events multiplies my } \\
\text { happiness. }\end{array}$ & $\begin{array}{l}\text { Activity and } \\
\text { dynamism }\end{array}$ & Social values \\
\hline $\begin{array}{l}\text { We do not humiliate } \\
\text { them and forgive } \\
\text { some of their } \\
\text { mistakes. }\end{array}$ & $\begin{array}{l}\text { Showing gentle } \\
\text { reactions to mistakes }\end{array}$ & Child rearing \\
\hline $\begin{array}{l}\text { We take part in } \\
\text { charities. }\end{array}$ & $\begin{array}{l}\text { Sympathy and } \\
\text { empathy }\end{array}$ & $\begin{array}{l}\text { Emotional } \\
\text { intelligence }\end{array}$ \\
\hline $\begin{array}{l}\text { We plan all our } \\
\text { actions. }\end{array}$ & Planning & Order and discipline \\
\hline $\begin{array}{l}\text { We do not eat fast } \\
\text { food that much. }\end{array}$ & $\begin{array}{l}\text { Having proper and } \\
\text { diverse diet. }\end{array}$ & Health and diet \\
\hline $\begin{array}{l}\text { I know sometimes } \\
\text { I should learn from } \\
\text { books or training } \\
\text { programs. }\end{array}$ & $\begin{array}{l}\text { Using others' } \\
\text { experiences }\end{array}$ & Growth \\
\hline We go on short trips. & $\begin{array}{c}\text { Being in the nature to } \\
\text { achieve peace }\end{array}$ & $\begin{array}{l}\text { Entertainment and } \\
\text { recreation }\end{array}$ \\
\hline
\end{tabular}

This table contains factors influencing family happiness from the mothers' viewpoint. First, open coding was carried out for raw statements, and axial codes were extracted from them. The result of the interviews with happy mother's included 105 raw statements. A total of 113 categories were obtained from open coding, and the following 13 categories were obtained from axial coding based on topical similarities: marital relationship quality, family interactions, positive health capital, life skills, spiritual values, social values, child rearing, emotional intelligence, order and discipline, health an diet, growth, recreation and happiness, and commitment to tradition and culture. For instance, the participant no. 17 stated: "we consult each other in doing things." Open coding: consulting family members on decisions; axial coding: proper family interactions (Figure 1).

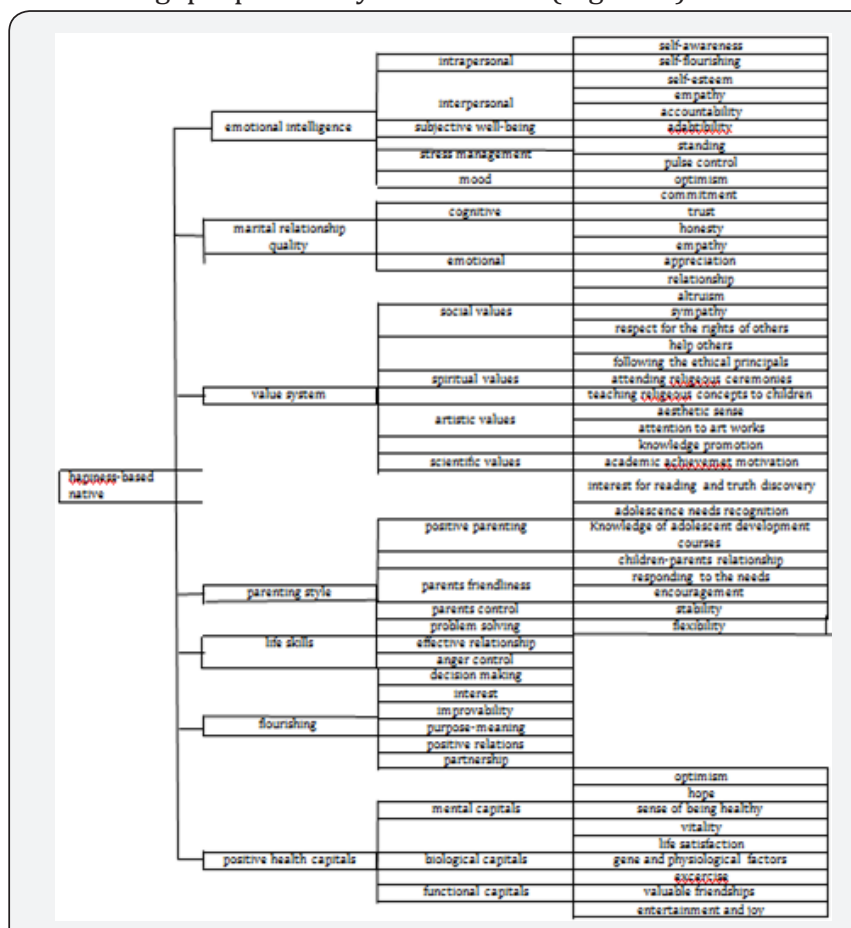

Figure 1: Notions (open codes, axial codes), and the main category (happiness-based native positive parenting model).

\section{Conceptual Model}

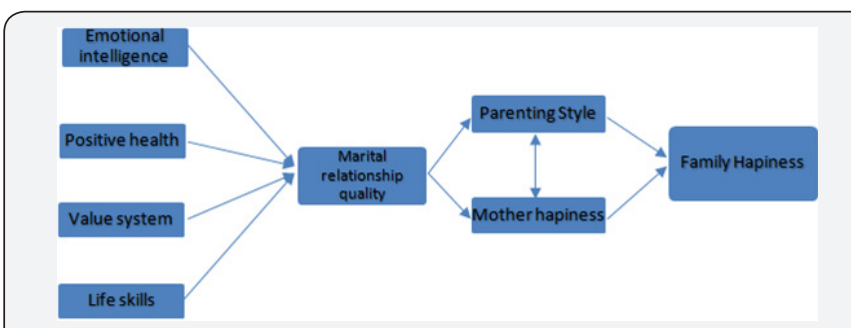

Figure 2: A graphical view of the grounded theory derived from the data associated with the factors influencing the family happiness

Considering the obtained notions and categories and their relationship with the central category, the grounded theory derived from the data can be presented (Figure 2). 
This theory reveals the relationships between categories. This theory can be stated as follows: Marital relationship quality as the central category, phenomenon, and issues including emotional intelligence, positive health, value system, and life skills contribute to enhanced marital relationship. Mothers' happiness as a strategy has some consequences leading to family happiness. To assess the validity of the proposed model, several experts were asked about their opinion regarding their conceptual model.

After designing and developing the happiness-based native parenting model based on literature and interviews with two groups of participants, an educational package was developed to help educating the happiness-based positive parenting concepts. That is, the model-based educational package was developed based on the following dimensions in eight 2-hour sessions: emotional intelligence, marital relationship quality, value

Table 4: The happiness-based native positive parenting model. system, parenting style, life skills, and flourishing. The package was then approved by three experts in the field of counseling and psychology. The sessions were focused on the following topics: life skills, marital relationship quality, and positive parenting, as well as the data derived from the Islamic lifestyle and real-life experiences of happy mothers who were interviewed.

Variables of the educational package were selected based on the following criteria:

a. The variables which could be educated in groups

b. The variables which could be educated considering the time frame

c. The most important variables

Table 4 demonstrates different educational session and their objectives and educational content (Table 4).

\begin{tabular}{|c|c|c|}
\hline Session & Session objectives & Session content \\
\hline First & $\begin{array}{l}\text { - Getting familiar with the group members and the group rules } \\
\text { - Getting familiar with parenting styles and methods }\end{array}$ & $\begin{array}{l}\text { After introducing himself/herself, } \\
\text { getting familiar with the group } \\
\text { members, describing session } \\
\text { rules, reaching agreement with } \\
\text { participants on group rules, and } \\
\text { briefly explaining the session } \\
\text { procedure, the trainer asked the } \\
\text { participants questions about } \\
\text { parenting styles. Then different } \\
\text { parenting or child-rearing styles } \\
\text { were explained. } \\
\text { Importance of } \\
\text { parenting skills to families } \\
\text { Emphasizing the } \\
\text { authoritative parenting style } \\
\text { Couples' support for } \\
\text { - } \quad \text { each other in parenting and } \\
\text { enhancing marital relationship } \\
\text { - } \quad \text { Local and foreign } \\
\text { studies on significance and effect } \\
\text { of parenting, especially during } \\
\text { adolescence, were discussed. } \\
\text { Carr (2012), Minoochin } \\
\text { (1974), Walsh (2012), and }\end{array}$ \\
\hline & & $\begin{array}{l}\text { Husseini (2011) } \\
\text { Task assignment }\end{array}$ \\
\hline
\end{tabular}




\begin{tabular}{|c|c|c|}
\hline Two & $\begin{array}{l}\text { Importance of family happiness and Seligman happiness education } \\
\text { method }\end{array}$ & 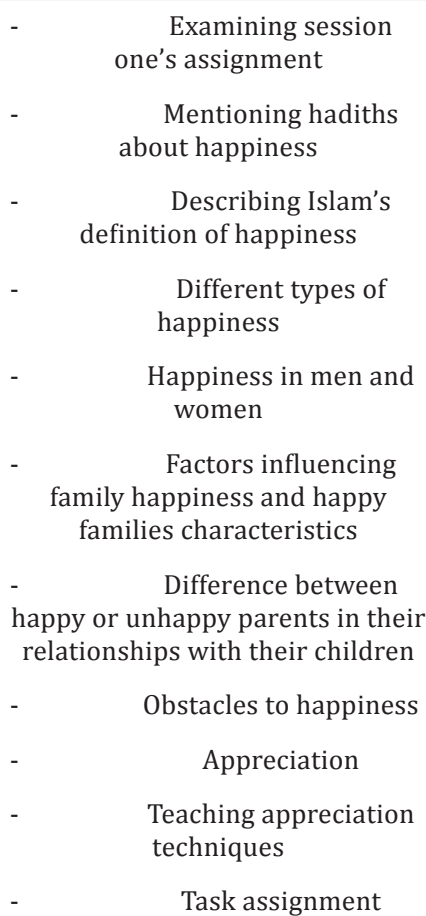 \\
\hline Three & Teaching happiness with Fordyce method & $\begin{array}{c}\text { - } \begin{array}{c}\text { Examining assignment } \\
\text { of the previous session }\end{array} \\
\text { - } \quad \text { Optimism and reduced } \\
\text { negative feelings aimed to } \\
\text { increase optimism in participants } \\
\text { - } \quad \text { Expressing negative } \\
\text { feelings properly } \\
\text { - } \quad \text { Teaching the technique } \\
\text { - Task assignment }\end{array}$ \\
\hline Four & Marital relationship quality & $\begin{array}{l}\text { - } \\
\text { session assignming the third } \\
\text { - } \quad \text { Expressing feelings and } \\
\text { desires } \\
\text { Listening and } \\
\text { sympathizing } \\
\text { - } \quad \text { Mutual boosting } \\
\text { - } \quad \text { Teaching simple marital } \\
\text { life skills } \\
\text { - } \quad \text { Task assignment }\end{array}$ \\
\hline Five & Getting familiar with the values & $\begin{array}{l}\text { Examining the session } \\
\text { four assignments } \\
\text { Explaining values } \\
\text { classification based on Allport } \\
\text { theory } \\
\text { Political, social, } \\
\text { religious, economic, artistic, and } \\
\text { scientific values } \\
\text { - Task assignment }\end{array}$ \\
\hline
\end{tabular}




\begin{tabular}{|c|c|c|}
\hline Six & Life skills & $\begin{array}{l}\text { - } \\
\text { Examining the session } \\
\text { - } \quad \text { Tive assignments } \\
\text { Teaching problem } \\
\text { solving skills } \\
\text { Teaching effective } \\
\text { - } \quad \text { communication skills } \\
\text { Teaching anger } \\
\text { - } \quad \text { management skills } \\
\text { Preparing members for } \\
\text { - } \quad \text { Task assignment }\end{array}$ \\
\hline Seven & Getting familiar with emotional intelligence skill & $\begin{array}{c}\text { - A brief review of } \\
\text { previous sessions } \\
\text { Examining previous } \\
\text { - } \quad \text { session assignment } \\
\text { areas of emotional intelligence in } \\
\text { accordance with Bar-On theory } \\
\text { - } \quad \text { Teaching sympathy, } \\
\text { conflict resolving, stress } \\
\text { management, and self- } \\
\text { management } \\
\text { - Ending training } \\
\text { sessions, conducting the post-test } \\
\text { assessment, and determining the } \\
\text { follow-up date }\end{array}$ \\
\hline
\end{tabular}

\section{Discussion and Conclusion}

The present study aimed to extract and develop a happinessbased native positive parenting model using the grounded theory. The results of qualitative analyses revealed that the happinessbased positive parenting model is composed of the following 7 components: emotional intelligence, marital relationship quality, value system, parenting style, life skills, flourishing, and positive health capitals. Each of these primary components is composed of sub-components that add up to 268 in total. After identifying the criteria and characteristics of happiness-based parenting and the proposed model, a review of previous research was carried out and the results were compared with those of the proposed model.

It should be mentioned that considering the results of most studies on factors influencing happiness, as well as opinions of the experts and interviewees participating in this research, little attention has been paid to the effect of marital relationship and its related factors. In fact, variables such as emotional intelligence, personality traits, life skills, and positive health capitals can improve marital relationship which in turn contributes to happiness. Evidence is reflective of a relationship between these variables and marital satisfaction. On the other hand, findings of this research revealed the effect of each of the aforementioned variables on family happiness. In general, the results of the present study are noteworthy, as it extracted the influencing factors on family happiness; then, based on the obtained results and by combining the two rich and diverse happiness programs (Seligman and Lyubomirsky) the happiness education was implemented.

The interview results showed that the abilities such as optimism, positive thinking, sympathy, accountability, selfawareness, self-respect, self-esteem, and etc. bring about happiness and effective management. Investigations also suggest that the emotional intelligence can impact mental wellbeing (Bar-On). In their investigations, Cheng and Furnham found that self-esteem, which is a component of emotional intelligence, was positively related to happiness. Studies conducted in Iran also indicated that people with high emotional intelligence levels had more responsible for their emotions; such people used their emotions to make decisions and respected other people's emotions. They also felt energetic and powerful not angry, respected other people's feelings, and showed sympathy, understanding and flexibility to others and their feelings [7]. In addition, regarding emotional intelligence, effective relationship between the couple is the most important characteristic of properly functioning families (Carr). Studies by Jalali [7], Siarouchi, Forgus, and Mayer [8], Sapington [9], Greef, Song, Golman [10], Stys and Broen, and Sheikhul Islami, Nejati, and Ahmadi [11] were consistent with these findings.

Marital relationship quality is a variable that influences family happiness. Chalbi and Mousavi [12] found that marital relationship based on trust ensured family happiness. Mookerjee 
and Beron stated that gender (being female) contributed to happiness. In an investigation, Guven, Senik, and Stichnoth indicated that a gap between the husband and wife happiness was a good predictor of divorce. However, the effect of happiness gap on divorce is not symmetrical. In other words, a marriage leads to divorce when the wife satisfaction with marital status is less than the husband's. The results of this research showed that increased marital relationship enhanced the mother's happiness which improves the family happiness. The importance of the mother role was also mentioned by Astone and Rothert.

Value system is another variable. For instance, as it was specified in the proposed model, if a person values health and physical wellness, he/she will allocate some time to daily workouts, proper diet, and soliloquys; these activities bring about happiness and mental health. We are sometimes dissatisfied because our job is not related to our values. Under such conditions, the person feels empty, desperate, and dissatisfied. Shared values are a substantial basis of sustainable marital relationship [13]. The finding of Suki [14], Maslash, Liter, and Rudin [4]; Paul; Pasandideh [15]; Abedi [16]; Fattahi, Neshatdoust, Rabiyi, and Sharifi [17] investigations were in line with our results.

Another influential variable in this regard is parenting style. Parents' agreement, collaboration, and cooperation in child rearing, and parents' concern for children's needs in proportion to their characteristics and growth phases were among the dimensions can influence personal life. Additionally, suitable treatment of children by parents in relation to their life phases, decisiveness in child rising; early training and development of skills were influencing parenting style. The effect of these dimensions can impact personal life, behavioral and mental performance of children. The study by Barker revealed that the interactions or the relationships between parents and children widely specified mental and physical growth of children. Some of the studies with similar findings include Hair, More, Madley, Kaye and Day; Samani, Khayer, and Sedaqat [18]; Gallarrin and Alonso; Kazdin; Kazdin and Whitely; Dilos Reezo and Kazdin [19]; and Shokouhi Yekta, Parand, and Faqihi [20].

In the developed model, life skills including items such as awareness and understanding of life problems, acceptance of problems, collaboration to solve problems logically, members' support for each other in solving problems, and adopting appropriate approaches for coping with life stress and tension. Investigations suggest that families using effective methods to solve problems display more adaptability (Carr). Furthermore, families establishing a good balance between spending time together or alone are happier and healthier [13]. In a study by Baghayi Moqadam, Malekpour, Amiri, and Mowlavi [21], the results reflected the relationship between life skills and improved performance of families. Positive health was found to be an effective variable on happily parenting. Findings by
Seligman [1,2] pointed to the actual effect of mental capitals (optimism, hope, and enthusiasm), biological capitals (genes), and functional capitals (exercise, valuable friendships, etc.) on well-being purposes.

Another variable in the developed model is flourishing. In this dimension, criteria such as passion, purpose, self-esteem, resilience, and positive relations are taken into account. Research results also support this finding. For example, Felicia Huppert and Timothy So of Cambridge University defined and examined flourishing for each of the 23 members of the European Union. Their definition of flourishing lies at the heart of the well-being theory. The findings show that there is a reciprocal relationship between positive emotions and positive intimate relations (Fredricsson). As a result, happy parents will have a close relationship with their children. These intimate relationships can affect some of the most important aspects of life (Ramsey and Gentzler). The parents experiencing a higher happiness and positive mood will raise their children with more positive experiences (Adam) which may improve the parent-children relationship (Lyable) [22,23].

Samples for this research were only selected from the population of first-grade female high school students of Qom City imposing limitations on generalizability of research findings which are meant to be a native model. The gender of the participants (females) selected to examine the effectiveness of the model can be considered another limitation of this study due to the personal differences between male and female students. Hence, the results of this research should be generalized with caution. Moreover, due to the unavailability and absence of the fathers, it was not possible to study and train them; as a result, we could not examine the effectiveness of this intervention. Hence, it is recommended to conduct studies involving the fathers. Considering the scope of positive psychology, and if happiness improvement is one of the goals of managers and authorities, it is recommended that this issue is given more emphasis. They should hold training courses to educate happiness-based positive parenting models to parents on order to establish the related culture among families and contribute to their health and survival.

\section{References}

1. Seligman M (2013) Subjective happiness. Translated by Mostafa Tabrizi, Ramin Karimi, and Ali Niloufari, Third Ediion, Tehran, Danzhe Press

2. Seligman M (2013) Flourishing. Translated by Amir Kamkar and Sakine Hozhabrian, ( $5^{\text {th }}$ edn.), Ravan Press, Tehran, Iran.

3. Sadatian A, Azar M (2010). Readiness and preparedness for marriage: spouse selection criteria and huge mistakes in choosing a spouse.Ma va Shoma Press, Tehran, Iran.

4. Maslash K, Liter MP (2009) Peace at work (application of professional burnout theory). Translated by Yousefi Z and Abadei MR Rasht, Gap Press. 
5. Lindolf T, Tayler B (2009) Qualitative research methods in communication sciences. Translated by Abdullah Givian, Hamshahri, Tehran, Iran.

6. Gall M, Walter B, Gall G (2004) Qualitative and quantitative research methods in educational and psychological sciences. Translated by Ahmadreza Nasr, Hamidreza Arizi, Mahmoud Abul Qasemi, Muhammad Jafar Pak Seresht et al., SAMT Press, Tehran, Iran.

7. Jalali A (2002) Emotional intelligence. Quarterly of Education. Journal of the Education School of Ministry of Education 69(70): 89-105.

8. Siaroji Zh, Forgus Zh, Mayer G (2005) Emotional intelligence in everyday life. Translated by Nouri Imam Zadehi A and Nasiri HA, Nashr-e No, Isfahan, Iran.

9. Sapington A (2015) Mental health. Translated by Hamidreza Hussein Shahi Baravati HR, ( $3^{\text {rd }}$ edn.), Ravan Press, Tehran, Iran.

10. Golman, Day (2013) Emotional intelligence (emotional self-awareness, self-containment, and helping others). Translated by Nasrin Parsa, Roshd Press, Tehran, Iran.

11. Sheikul Islami R, Nejati A, Ahmadi S (2011) Predicting components of happiness in married women based on self-esteem and marital relations. Woman in Culture and Art (Women's Studies) 3(1): 52-37.

12. Chalbi M, Mousavi M (2009). A sociological study of factors influencing happiness on the macro and micro levels. Iran's Sociology Journal $9(1,2): 34-57$.

13. Olson DG, Defrin G, Olson A (1999) Marriage skills and effective marital relationships. Translated by Ahmadreza Bohehrayi and Nader Fathi (2011). Psychology and Art Publications.
14. Soki Nik D, Bandat V, Raufman F (2005) Professional preparedness program. Translated by Faraji, M. Roshd Press, Tehran, Iran.

15. Pasandideh A (2012) Islamic model of happiness. Qom, Dar al-Hadith Press.

16. Tagarian N (2008) Analysis of effect of spiritual couple therapy on family mood and happiness of couples in Khomeini Shahr. M.A. thesis of family consulting. Isfahan University, Isfahan, Iran.

17. Fattahi R, Neshat Doust H, Rabiyi M, Shairifi A (2011) Analysis of the relationship between happiness and spiritual tendencies in Isfahani students. Islam and Psychology Studies, 5: 8.

18. Samani S, Khayyer M, Sedaqat Z (2010) Parenting styles in different kinds of family in the family content process. Family Research Quarterly 6(22): 161-174.

19. Zarakar K, Jafari F (2010) Family consulting: notions, history, process, and theories. Arasbran Press, Tehran, Iran.

20. Shokouhi Yekta M, Parand A, Faqihi AN (2006) A comparative analysis of parenting styles. Islamic Education Quarterly 2(3): 115-140.

21. Baghayi Moqadam, G Malekpour, M Amiri, Sh Mowlavi H (2011) Effect of teaching life skills on happiness and anger management of adolescents suffering physical and motor disabilities. Behavioral Sciences Journal 5(4): 305-310.

22. Borjali A (2001) Personality evolutions in adolescents. Varaye Danesh Press.

23. Rabbani R, Rabbani A, Ganji M (2011) A sociological approach to happiness of household custodians in Isfahan City. Iran's Social Problems Journal, second year 1: 39-73. 